\title{
Effects of habitat heterogeneity in seagrass beds on grazing patterns of parrotfishes
}

\author{
Silvia Maciá ${ }^{1,3, *}$, Michael P. Robinson ${ }^{1,2}$ \\ ${ }^{1}$ Hofstra University Marine Laboratory, PO Box 90, St. Ann's Bay, Jamaica, West Indies \\ ${ }^{2}$ Department of Biology, University of Miami, PO Box 249118, Coral Gables, Florida 33124, USA \\ ${ }^{3}$ Present address: Barry University, School of Natural and Health Sciences, 11300 NE 2 Avenue, Miami Shores, \\ Florida 33161, USA
}

\begin{abstract}
Habitat heterogeneity, particularly patchiness in seagrass cover, greatly affects the community dynamics of seagrass ecosystems. Heterogeneity in seagrass habitats can also be caused by unvegetated patches within the otherwise continuous seagrass cover. Blowouts are bare areas with an eroding edge that forms a vertical wall, often with overhanging seagrass roots and rhizomes. Fishes, including parrotfishes, aggregate in these blowouts. These aggregations of herbivorous fishes might influence the structure of the adjacent seagrass habitat. We compared parrotfish Sparisoma spp. grazing patterns at different distances from the edge of blowouts in seagrass beds (mainly Thalassia testudinum) at St. Ann's Bay, Jamaica, by counting and measuring the number of bite marks on the seagrass blades. The percentage of grazed blades, number of bites per blade, and total area of seagrass removed by grazing all increased with increasing distance from the edge of the blowout. However, the size of the bite marks, which is indicative of the size of the fish that made them, was significantly larger near the blowout than at further distances. Few large bites were found at distances greater than $4 \mathrm{~m}$ from the blowout, while small bites were more abundant at distances further from the edge. These data suggest that larger fishes feed in closer proximity to the shelter of the blowouts, while smaller fishes avoid the blowout edge. Both seagrass morphology and parrotfish grazing characteristics were significantly different among the blowouts used in the study, indicating that blowouts in and of themselves increase the structural heterogeneity of seagrass beds. Thus, blowouts affect the structure of seagrass ecosystems directly and indirectly (via their effects on the grazing behavior of parrotfishes).
\end{abstract}

KEY WORDS: Habitat heterogeneity · Grazing · Blowouts · Parrotfishes · Thalassia testudinum • Seagrass Resale or republication not permitted without written consent of the publisher

\section{INTRODUCTION}

Habitat heterogeneity can have important effects on the structure and function of seagrass beds. Patchiness in bottom cover can affect seagrass growth and survivorship (Ramage \& Schiel 1999) and shoot density (Hovel et al. 2002). In addition, seagrass patchiness affects the broader community through changes in local sediment size (Bowden et al. 2001), abundance of fishes and shrimps (Murphey \& Fonseca 1995, Hyndes et al. 2003, Salita et al. 2003), survivorship, growth and predation rates of bivalves and crabs (Irlandi \& Peterson 1991, Irlandi 1994, Irlandi et al. 1995, Hovel et al. 2002), and infaunal species richness (Bowden et al. 2001). The aforementioned studies have considered habitat heterogeneity in terms of size, shape and connectivity of isolated patches of seagrass. Small, unvegetated areas within an otherwise continuous seagrass bed also increase habitat heterogeneity. Such bare areas can be caused by localized grazing (Bjorndal 1980, Williams 1988, Valentine \& Heck 1991), by bioturbation (Fonseca et al. 1996, Townsend \& Fonseca 
1998), or by abiotic factors (Scoffin 1970, Patriquin 1975). The heterogeneity caused by these bare areas, however, has received relatively little attention.

Blowouts are bare or sparsely vegetated open areas in an established seagrass bed (Patriquin 1975). Blowouts are most commonly caused by persistent wave or current activity that erodes part of the sediment and seagrass root/rhizome mat (Scoffin 1970, Patriquin 1975). These bare areas are often crescentshaped, with a vertical wall (scarp) along a clearly defined eroding edge. The unvegetated area of the blowout is usually deeper than the surrounding seagrass bed, and the scarp may have a vertical relief of up to $80 \mathrm{~cm}$ (Patriquin 1975, and present study). Sections of the root/rhizome mat often hang over and down along the scarp, creating crevices in which many fishes can be found (M. P. Robinson pers. obs.).

The presence of blowouts creates unique microhabitats within the continuous canopy of a dense seagrass bed. Some of these microhabitats, such as the seagrass root/rhizome mats that overhang the scarp, could be used by various fishes as refugia for avoiding predators. At least 23 species from 14 families of fishes are found in blowouts during the day (M. P. Robinson et al. unpubl. data). If used as refugia by herbivorous fishes, blowouts could have significant effects on the surrounding seagrass. Because smaller fishes can hide more easily within the seagrass canopy than can larger fishes, the effectiveness of blowouts relative to the seagrass canopy as protection from predators probably depends on the size of the fish. Accordingly, we predict that larger fishes spend more time near blowouts than in the seagrass. In particular, the parrotfishes Sparisoma radians, $S$. chrysopterum, and $S$. rubripinne, which are associated with seagrass habitats and graze live seagrass blades (Randall 1965, 1967, Lobel \& Ogden 1981, Macintyre et al. 1987, Montague et al. 1995, McAfee \& Morgan 1996) are often found in and around seagrass blowouts (M. P. Robinson et al. unpubl. data).

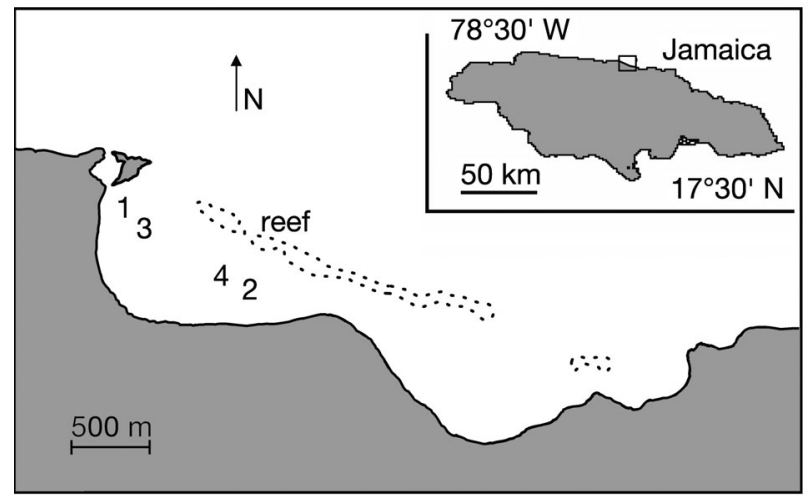

Fig. 1. Study site in St. Ann's Bay, north coast of Jamaica. 1 to 4 : blowouts examined in this study
Our study was designed to answer the following questions: (1) do parrotfishes of different sizes use blowouts differently and, if so, (2) is there a difference in grazing effects on the seagrass at different distances from the blowouts? Parrotfishes are well-camouflaged and difficult to observe in seagrass beds. When feeding on seagrass blades, however, these fishes leave a distinct hemispherical bite mark on the blade (Greenway 1976, Montague et al. 1995, Kirsch et al. 2002). Therefore, we used an indirect approach to answer our research questions, with bite marks acting as a proxy for direct observations of the fishes themselves. This is the first study to investigate the use of blowouts by fishes and its potential consequences for the nearby seagrass population.

\section{MATERIALS AND METHODS}

Study site. We conducted our study in the seagrass beds of St. Ann's Bay, Jamaica (Fig. 1). Bottom cover in St. Ann's Bay consists primarily of dense Thalassia testudinum beds (aboveground biomass $=1100$ to $1400 \mathrm{~g} \mathrm{~m}^{-2}$, S. Maciá unpubl. data). We identified 11 blowouts in the western side of the bay, and randomly selected 4 whose eroding edge was isolated by at least $50 \mathrm{~m}$ from the next nearest blowout. These 4 blowouts were of varying size and depth (Table 1).

Parrotfish grazing and seagrass morphometrics. Because we used bite size as a proxy for actual fish size, it was necessary to definitively establish the relationship between bite size and fish length. We used a drop-net to capture 5 individuals of the parrotfish Sparisoma chrysopterum, 8 S. rubripinne, and $3 S$. radians. We measured total length (TL) and placed the fish individually into 901 outdoor aquaria with an open seawater system. Each tank had 4 seagrass 'shoots' consisting of 3 or 4 blades (approximately $200 \mathrm{~mm}$ length) of unbitten Thalassia testudinum held together with a clothespin such that the blades floated upright in the water column. We maintained the fishes in the aquaria until they had made at least 10 bites each on the seagrass blades ( 1 to $2 \mathrm{~d}$ ). We then removed the seagrass leaves from the tanks, dried them, flattened

Table 1. Characteristics of blowouts examined in this study

\begin{tabular}{|lcccc|}
\hline Blowout & $\begin{array}{c}\text { Length } \\
(\mathrm{m})\end{array}$ & $\begin{array}{c}\text { Width } \\
(\mathrm{m})\end{array}$ & $\begin{array}{c}\text { Scarp height } \\
(\mathrm{cm})\end{array}$ & $\begin{array}{c}\text { Water depth } \\
(\mathrm{m})\end{array}$ \\
\hline 1 & 15 & $3-8$ & $30-60$ & 1.5 \\
2 & 62 & $5-10$ & $30-60$ & 1.3 \\
3 & 13 & 1 & $30-50$ & 0.5 \\
4 & 19 & $1-2$ & $20-30$ & 3.0 \\
\hline
\end{tabular}


them on a scanner and digitized their image into a computer (sensu Kirsch et al. 2002, O'Neal et al. 2002). We randomly selected 10 complete bites from each aquarium and, using SigmaScan (Jandel Scientific) image-analysis software, measured their maximum width. Bites were considered complete when they were hemispherical and the entire arc of both sides was evident.

To quantify parrotfish grazing in the field, we laid out 8 transects of $10 \mathrm{~m}$ perpendicular to the eroding edge of each blowout. The transects were approximately $1.5 \mathrm{~m}$ apart at the edge of the blowout but fanned outwards, as the blowouts were crescentshaped. Seagrass samples were collected at 5 distances along each transect: $0,2,4,7$ and $10 \mathrm{~m}$ from the eroding edge. At each distance we hand-collected all seagrass blades within a $0.01 \mathrm{~m}^{2}$ quadrat. The nonbitten blades of 1 quadrat at Blowout 1, $7 \mathrm{~m}$ distance from the eroding edge, were lost prior to counting.

We measured the length and width of 2 randomly selected seagrass blades from each of the above quadrats from Blowouts 2, 3 and 4. All other analyses used samples from all 4 blowouts. We counted the total number of bites (complete and incomplete) on every blade. Because there was a significant effect of distance from the blowout on seagrass length (see 'Results'), we standardized bite number as a function of seagrass length. We divided the number of bites on each blade by the average length of seagrass blades for that distance from the blowout. Seagrass blades with bites were patted dry and immediately scanned into a computer. We used image-analysis software to measure the maximum widths of all complete bites and the total area of each of 40 randomly selected bites ( 2 from each distance from each blowout). Within this subset of 40 bites, area increased with increasing bite width, and a second-order regression fit these data significantly $\left(\mathrm{r}^{2}=0.93 ; \mathrm{p}<0.001 ; \mathrm{n}=40\right)$. We then used this regression to convert the width of each complete bite to an area.

Statistical methods. Individual parrotfishes tend to make multiple bites on the same seagrass blade while feeding (M. P. Robinson pers. obs.). To avoid pseudoreplication, we calculated a mean per quadrat for each type of grazing datum (i.e. number of bites per blade, proportion of blades grazed, bite width, total seagrass area grazed) and used these means as replicates in our statistical analyses. We performed a multivariate analysis of variance (MANOVA) using all seagrass and grazing data as dependent variables of the fixed factor distance and a blocked factor, blowout number. Blowouts were analyzed as blocks rather than as part of a fully factorial 2-way ANOVA, because replicates of a 2-way ANOVA must be completely randomized (Sokal \& Rohlf 1995), an impossi- bility in our case given the pre-existing differences among the blowouts (Table 1). In the MANOVA, the distance effect was significant (Wilk's $\lambda=0.628$, $\left.F_{8,149}=11.017, \mathrm{p}<0.001\right) ;$ therefore we analyzed each variable independently. We analyzed all of the dependent factors from the MANOVA with separate randomized-block ANOVA, with the blowouts as blocks and distance as a fixed factor. Tukey's honest significant difference (HSD) test was used for post-hoc analyses. Seagrass blade length data were boxcox-transformed and the number of bites $\mathrm{cm}^{-1}$ blade length was square-root-transformed prior to analysis. All other non-transformed data satisfied the assumptions of ANOVA.

Because the ANOVA of bite width found a significant effect of distance (Table 2), we examined more closely the relationships of large ( $\geq 7 \mathrm{~mm}$, see 'Results') and small ( $\leq 7 \mathrm{~mm}$ ) bites with distance from the blowout. We standardized the number of bites as number $\mathrm{cm}^{-1}$ seagrass blade length. The number of small bites $\mathrm{cm}^{-1}$ seagrass was square-root-transformed and analyzed with an ANOVA. Because there was a large number of quadrats without any large bites (i.e. resulting in many zeros in the data set), it was not possible to use parametric analyses. Therefore, we used a bootstrapped 1-way ANOVA to determine the overall significance of distance on the number of large bites. For post-hoc analyses we used multiple, Bonferroni-corrected $(k=10)$ bootstrapped ANOVA comparing each pair of distances. This type of analysis is analogous (but not equivalent in calculation) to Tukey's HSD test, because we used unplanned comparisons to compare individual groups. Where noted, we corrected p-values with a Bonferroni correction calculated using the sequential Dunn-Šidák procedure (Sokal \& Rohlf 1995).

\section{RESULTS}

For each parrotfish species we calculated a linear geometric mean (GM) regression between TL and mean bite width in captivity. These regressions did not differ based on their 95\% confidence intervals (Jolicoeur \& Mosimann 1968); therefore we combined the data for the 3 species. The combined GM regression of bite width on fish TL was significant $\left(\mathrm{r}^{2}=0.83\right.$; $\mathrm{p}<$ 0.001; $\mathrm{n}=16$ ) and positive (Fig. 2); therefore bite width is an appropriate indicator of the length of the fish that created the bite mark.

As distance from the blowout increased, the length of the seagrass blades increased significantly (Table 2, Fig. 3a). There was no effect of distance on the width of the blades, however (Table 2, Fig. 3b). The density of the seagrass blades increased significantly with increasing distance from the blowout (Table 2, Fig. 3c). 
Table 2. Results of randomized-block univariate ANOVA on various seagrass Thalassia testudinum and parrotfish grazing parameters. Distance from edge of blowout is main factor and blowout is blocked factor

\begin{tabular}{|c|c|c|c|c|c|}
\hline Seagrass/grazing parameter & Source & df & MS & $F$ & $\mathrm{p}$ \\
\hline \multirow[t]{3}{*}{ Blade length } & Distance & 4 & 11473.860 & 5.514 & $<0.001$ \\
\hline & Blowout & 3 & 131122.015 & 63.012 & $<0.001$ \\
\hline & Error & 233 & 2080.904 & & \\
\hline \multirow[t]{3}{*}{ Blade width } & Distance & 4 & 2.452 & 0.872 & 0.482 \\
\hline & Blowout & 3 & 48.205 & 17.327 & $<0.001$ \\
\hline & Error & 233 & 2.782 & & \\
\hline \multirow[t]{3}{*}{ Blade density } & Distance & 4 & 660.404 & 4.674 & $<0.001$ \\
\hline & Blowout & 3 & 5689.133 & 40.264 & $<0.001$ \\
\hline & Error & 151 & 141.296 & & \\
\hline \multirow[t]{3}{*}{ No. bites $\mathrm{cm}^{-1}$ blade } & Distance & 4 & 0.034 & 5.645 & $<0.001$ \\
\hline & Blowout & 3 & 0.143 & 24.091 & $<0.001$ \\
\hline & Error & 152 & 0.006 & & \\
\hline \multirow[t]{3}{*}{$\%$ Grazed blades } & Distance & 4 & 0.070 & 5.896 & $<0.001$ \\
\hline & Blowout & 3 & 0.439 & 36.704 & $<0.001$ \\
\hline & Error & 151 & 0.012 & & \\
\hline \multirow[t]{3}{*}{ Bite width } & Distance & 4 & 8.920 & 11.841 & $<0.001$ \\
\hline & Blowout & 3 & 11.921 & 15.825 & $<0.001$ \\
\hline & Error & 152 & 0.753 & & \\
\hline \multirow[t]{3}{*}{ No. small bites $\mathrm{cm}^{-1}$ blade } & Distance & 4 & 0.113 & 14.892 & $<0.001$ \\
\hline & Blowout & 3 & 0.132 & 17.312 & $<0.001$ \\
\hline & Error & 152 & 0.008 & & \\
\hline \multirow[t]{3}{*}{ Total seagrass area removed } & Distance & 4 & 45910.216 & 6.986 & $<0.001$ \\
\hline & Blowout & 3 & 22181.407 & 3.375 & 0.020 \\
\hline & Error & 152 & 6571.580 & & \\
\hline
\end{tabular}

These increases in length and density indicate an overall increase in above-ground biomass with increasing distance from the edge of a blowout. The blocked blowout factor significantly affected seagrass blade length, width, and density (Table 2).

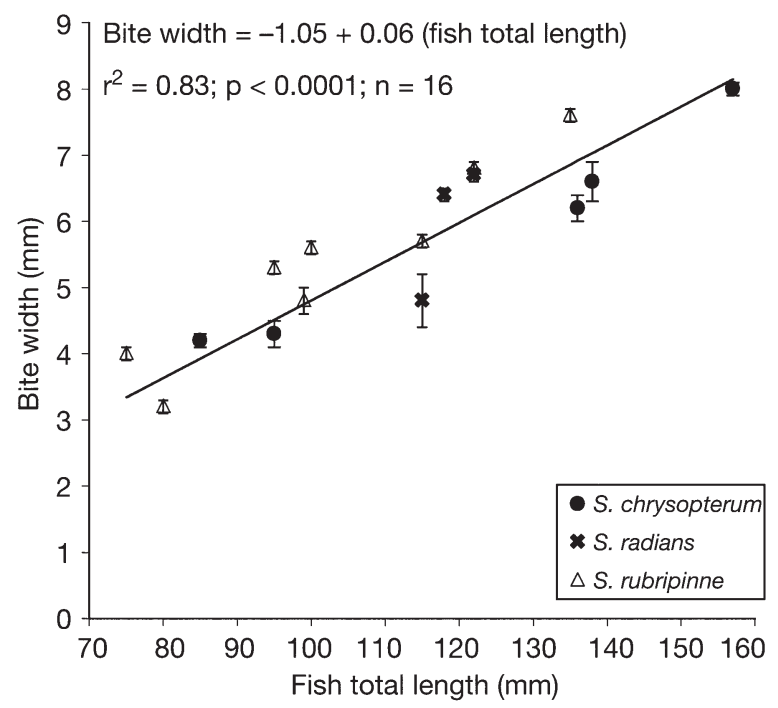

Fig. 2. Sparisoma spp. Regression between fish total length and bite width for 3 parrotfish species maintained in aquaria. Each data point represents mean bite width $( \pm \mathrm{SE})$ for a single fish
Distance from the blowout had a strong effect on grazing intensity. There was a significant effect of distance from the blowout on the mean number of bites $\mathrm{cm}^{-1}$ seagrass blade (Table 2). Seagrass blades at the edge of the blowout had significantly fewer bites per unit blade length than blades farther away (Fig. 4a). The proportion of blades with at least 1 bite also increased significantly with increasing distance from the blowout (Table 2, Fig. 4b). The blocked blowout factor significantly affected both number of bites $\mathrm{cm}^{-1}$ blade and proportion of grazed blades (Table 2).

Distance from the blowout significantly affected the mean width of bites (Table 2). Bites at the edge of the blowout $(0 \mathrm{~m})$ were significantly wider than at all other distances, but there was no difference among the other 4 distances (Fig. 4c). Bite width was also significantly affected by the blocked blowout factor (Table 2). To test whether the frequency distributions of bite widths differed as a function of distance, we compared all possible combinations of distances with Bonferroni-corrected $(k=10) 2$-sample Kolmogorov-Smirnov tests. The distribution of bite widths at $0 \mathrm{~m}$ differed significantly from the distributions at all other distances (4 tests: all $\mathrm{p}<0.008$ ), and the distribution at $4 \mathrm{~m}$ differed from the distribution at $7 \mathrm{~m}(\mathrm{p}<0.01)$. None of the other distributions differed significantly from one another.

The distribution of bite widths at the edge of the blowout had a significant right skew $\left(g_{1} \pm \mathrm{SE}=1.183\right.$ 


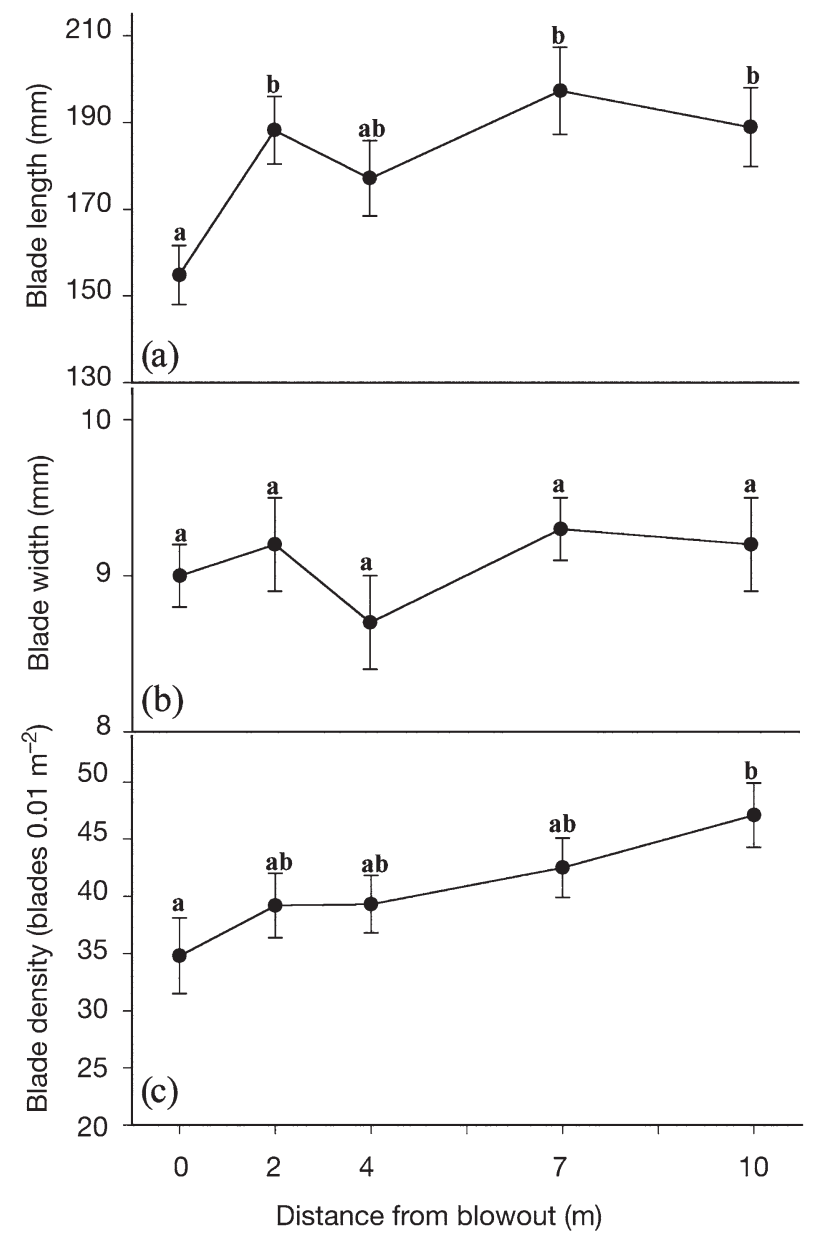

Fig. 3. Thalassia testudinum. Blade morphometrics and density as a function of distance from edge of blowout. Here and in Fig. 4, data points are mean $\pm \mathrm{SE}$, and values with same letter are not significantly different from each other (Tukey's post-hoc analysis)

\pm 0.120 ), indicating a high frequency of large bites (Fig. 5). The widths of all observed bites ranged from 1.13 to $12.45 \mathrm{~mm}$. Subsequently, we defined a large bite as being $\geq 7 \mathrm{~mm}$, the approximate midpoint of this range. We square-root-transformed the number of small bites $\mathrm{cm}^{-1}$ seagrass blade. There were significantly more small bites per length of seagrass blade at $10 \mathrm{~m}$ from the blowout and fewer small bites at 0 and $2 \mathrm{~m}$ than at any other distance (Table 2; Fig. 5). The large number of quadrats without any large bites made parametric tests suspect. We therefore performed a bootstrapped 1-way ANOVA which found a significant effect of distance on the number of large bites per length of seagrass (10000 iterations, $F=$ 2.630, $p=0.031$ ). Post-hoc analyses found that there were significantly more large bites in the quadrats at $0 \mathrm{~m}$ than at 4,7 or $10 \mathrm{~m}$ (Fig. 5). No other distances differed significantly. At distances beyond $2 \mathrm{~m}$ large bites were rare.

We used our second-order regression to convert each bite width to an area. We then summed the area of all bites in each quadrat to estimate the total seagrass blade area removed by grazing. These data showed a significant effect of distance from the blowout on total seagrass area removed (Table 2). The total area of seagrass blade material removed by grazing parrotfishes increased with increasing distance from the blowout (Fig. 4d). Total seagrass area removed differed significantly among the blowouts (Table 2).

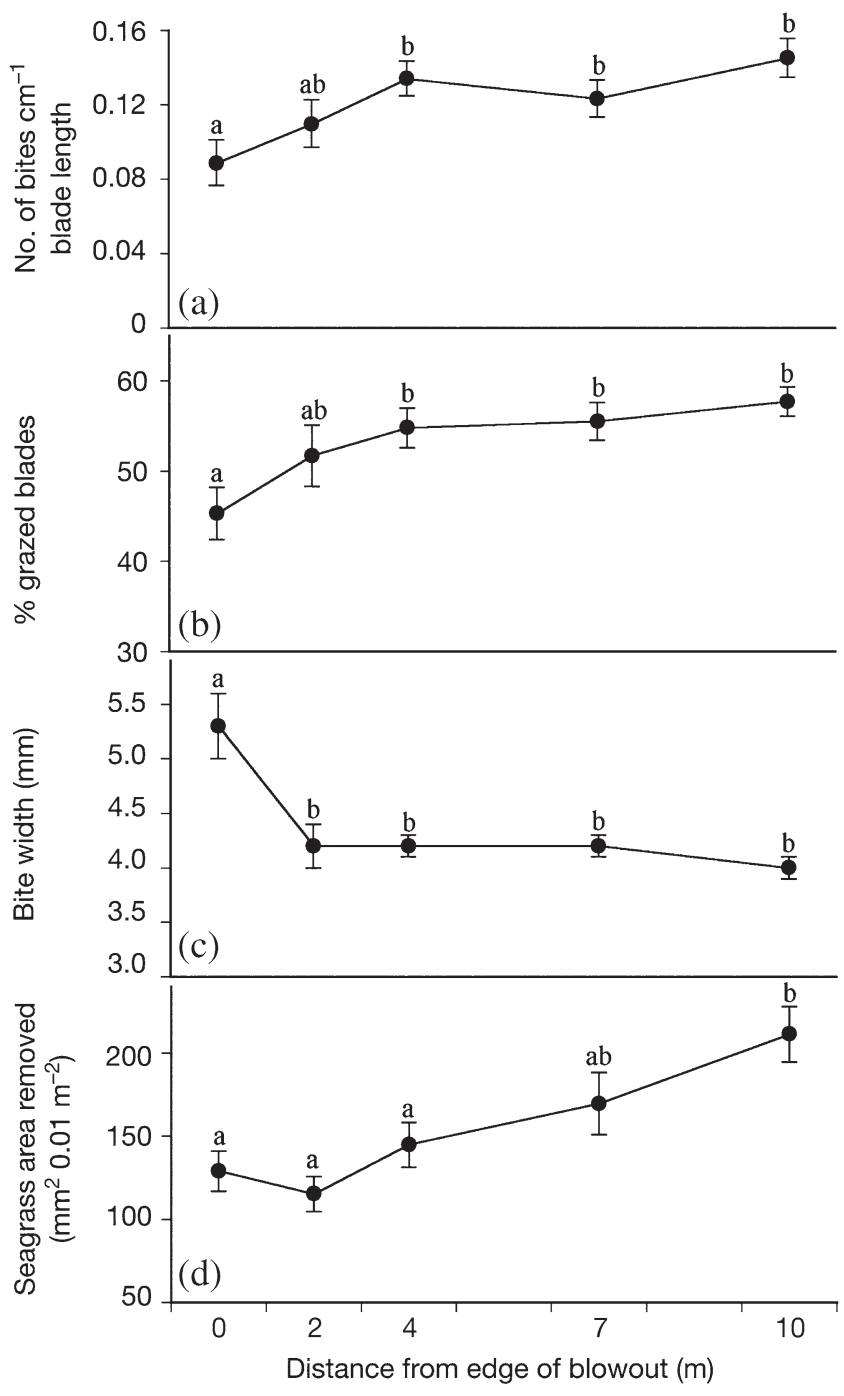

Fig. 4. Thalassia testudinum. Grazing effects by parrotfishes as a function of distance from edge of blowout. (a) Mean no. bites $\mathrm{cm}^{-1}$ seagrass blade length (back-transformed from original square-root-transformed data); (b) percentage seagrass blades with at least 1 bite; (c) mean width of parrotfish bites; (d) total seagrass blade area removed by parrotfish grazing (calculated by converting bite widths to bite area, then summing all bite areas for each $0.01 \mathrm{~m}^{2}$ quadrat) 


\section{DISCUSSION}

Blowouts are common features of many seagrass beds, but until now their effect on the surrounding community has been largely ignored. Our data indicate that blowouts could have significant effects on the local seagrass community. Every dependent variable we measured, whether a characteristic of the seagrass or of the grazing of the parrotfishes, differed significantly among blowouts (Table 2). Despite the small

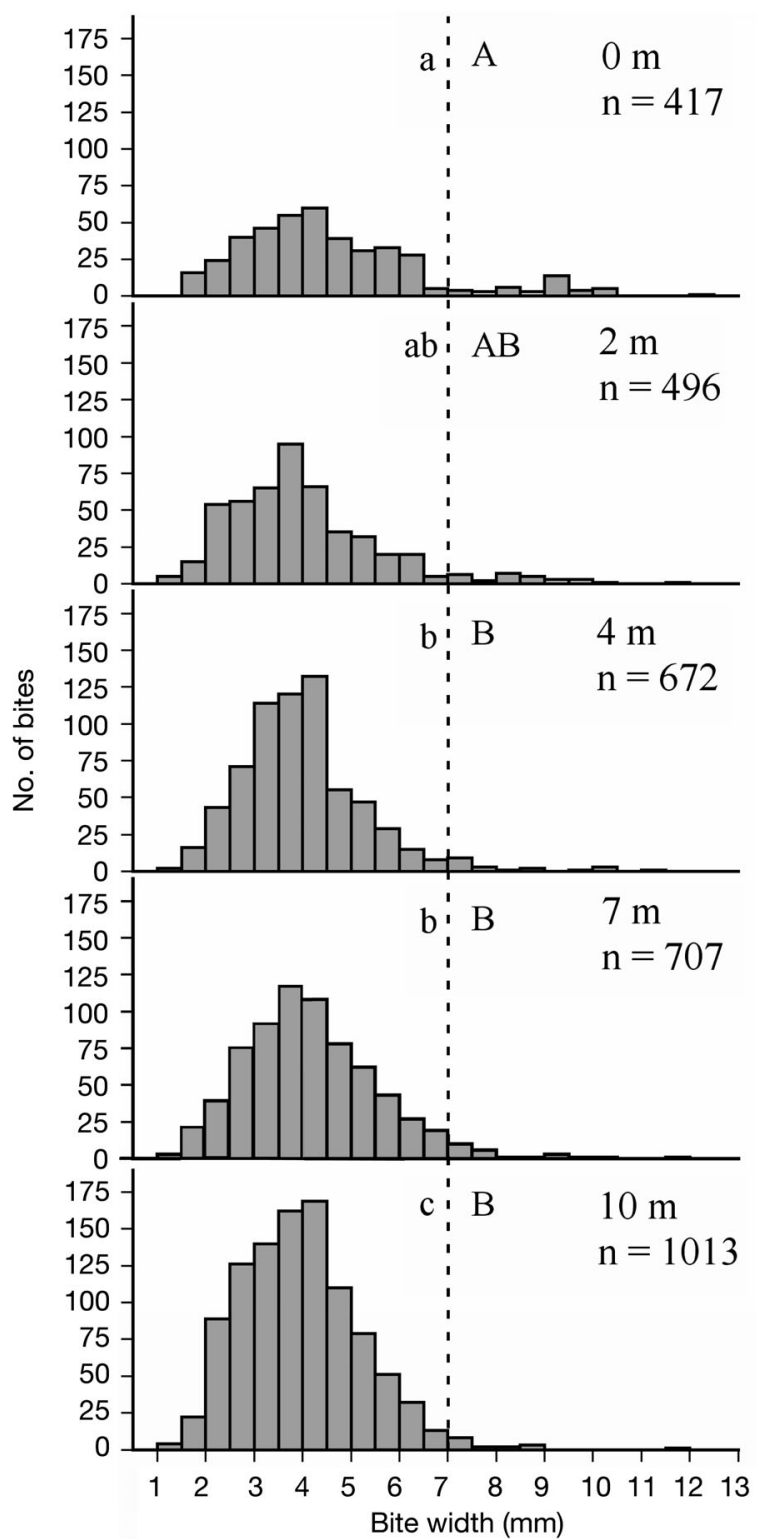

Fig. 5. Thalassia testudinum. Size-frequency histograms of width of bites made by parrotfishes on seagrass blades for each distance $(0,2,4,7,10 \mathrm{~m})$ from edge of blowout. Different letters indicate size-frequency distributions that are significantly different from each other for small bites (left of vertical line) and large bites (right of vertical line) size of the blowouts relative to the surrounding seagrass bed, it appears that differences in size, shape, location, and possibly other unidentified features can lead to significantly different effects on the nearby seagrass community. The variation among blowouts had, in most cases, a stronger influence on the dependent variables than did the effect of distance from the edge of the blowout. Blowouts accounted for $5.3-42.6 \%$ of the variation in the dependent variables compared to $1.2-19.2 \%$ accounted for by distance (Table 2). Such a strong effect suggests that blowouts, despite their small size, could play important roles in seagrass ecosystems. Because of the many measured (Table 1) and unmeasured differences that were uncontrolled among the blowouts, however, it is difficult to interpret these effects in light of the differences among blowouts.

It is possible that the blowout-derived variation observed here is not specific to blowouts but simply results from edge effects common to sand-seagrass interfaces. Many seagrass beds have bare areas without the 3-dimensional complexity of blowouts. Although we did not investigate the effects of such bed edges, we believe that our results are specific to blowouts. In the Philippines, the abundance of fishes is not correlated with either the complexity of sand-seagrass edges nor with the shape of seagrass patches (Salita et al. 2003). More importantly, the blowout scarp, which can be up to $60 \mathrm{~cm}$ high and overhung by a complex mat of seagrass rhizomes, is a unique microhabitat. Simple edges between vegetated and unvegetated areas would not necessarily provide effective refugia from predation, and would not be likely to cause a difference in behavior of fishes of different sizes.

Parrotfish grazing was significantly affected by proximity to a blowout. Total grazing pressure increased with increasing distance from the edge of the blowouts, and this effect could be seen within as little as $4 \mathrm{~m}$ from the edge. There were significantly more bites $4 \mathrm{~m}$ from the blowout than immediately at the blowout edge. The proportion of blades with at least 1 bite was also significantly higher at distances at least $4 \mathrm{~m}$ from the blowout than at 0 or $2 \mathrm{~m}$ from the blowout. The size of the bites, however, was significantly larger at the edge of the blowout than at any of the farther distances. Although individual bites near the blowout were larger, they were also much fewer in number. Thus, the overall impact of grazing parrotfishes on the seagrass (total area of seagrass blade removed) increased significantly with increasing distance from the blowout. Compared to seagrasses farther from the blowout, seagrasses closer to the edge of the blowout lose less above-ground biomass to parrotfish grazers.

Grazing by parrotfishes in the Florida Keys is variable on a scale of 100s of meters (Kirsch et al. 2002). Such a 
large area might include a number of different microhabitats and parrotfish populations. Our study has shown that there can be significant variability in grazing over much smaller scales (i.e. $<10 \mathrm{~m}$ ). Although parrotfishes of all sizes easily swim and feed over distances $>10 \mathrm{~m}$ in less than $1 \mathrm{~min}$ (M. P. Robinson pers. obs.), the presence of a blowout appears to limit the foraging area and thus the spatial impact of certain grazers (larger parrotfishes) on the seagrass population.

Bites were significantly larger at the edge of the blowout than at all other distances. This pattern was caused by a greater number of large bites (i.e. $\geq 7 \mathrm{~mm}$ width) and fewer small bites near the blowout edge (Fig. 5). It is unlikely that the large bites at each blowout (which were relatively fewer than the small bites and were found mostly at $0 \mathrm{~m}$ ), were created by a single large fish and represent pseudoreplication. These bites ranged from 7.0 to $12.4 \mathrm{~mm}$ in width (Fig. 5), corresponding to fishes of 137 to $230 \mathrm{~mm} \mathrm{TL}$, a relatively large range of $93 \mathrm{~mm}$.

The decrease in bite size with increasing distance from the edge indicates that larger parrotfishes feed more along the edge of the blowout than at distances farther into the seagrass bed, whereas smaller parrotfishes exhibit the opposite pattern. There are several potential and non-exclusive explanations for this pattern. It is unlikely that smaller fishes are capable of excluding larger fishes from a preferred habitat. In addition, differences in resource availability with distance do not explain the more intense grazing of larger fishes near the blowout edge, because there is actually less above-ground seagrass biomass closest to the blowout. Therefore, it appears that larger fishes prefer the blowout edges. The remaining question then is whether the smaller fishes are excluded from the blowout edge by the larger fishes or whether the smaller fishes prefer to forage in the seagrass further from the blowout. Despite the significant differences in seagrass morphometrics, there is nevertheless a high biomass of seagrass at each distance. Therefore, competition for this resource seems an unlikely explanation for the greater presence of smaller fishes further from the blowout.

A better explanation of the differences between fish size classes in feeding is that larger fishes require the refuge provided by the blowout. Smaller parrotfishes that can penetrate and hide among the seagrass blades are probably less constrained in their needs for refugia and can feed further from the blowouts. These fishes might prefer the greater above-ground biomass farther from the blowout. Parrotfishes associated with coral reefs use the reef as a refuge when not feeding, but leave its shelter for feeding bouts in nearby seagrass beds (Randall 1965, Ogden \& Zieman 1977, Tribble 1981, Macintyre et al. 1987). Furthermore, mean bite size on seagrass blades decreases with increasing distance from a patch reef (Ogden \& Zieman 1977), a pattern similar to that which we found for blowouts. Ogden \& Zieman (1977) attributed this pattern to the fact that larger fishes (20 to $40 \mathrm{~cm}$ ) cannot use the seagrass canopy itself as a refuge from predation, while smaller fishes $(<15 \mathrm{~cm})$ move freely through the seagrass canopy at all times of the day. A similar pattern occurs in beds of seagrasses with different morphologies (Hyndes et al. 2003). The seagrass Amphibolis griffithii has a dense canopy of leaves that is elevated above the sediment by the stems, creating an open space beneath. Fishes inhabiting this seagrass are larger than those in beds of Posidonia spp., the leaves of which emerge directly from the sediment surface. Hyndes et al. (2003) attribute this size difference to the ability of smaller fishes to penetrate the dense canopy of Posidonia spp. leaves, while the larger fishes are able to move about in the space underneath the A. griffithii canopy.

Our data suggest that blowouts, like coral reefs and the seagrass Amphibolis griffithii, increase habitat complexity and provide a refuge for larger parrotfishes that cannot hide within the canopy of strap-shaped seagrass blades. When using blowouts as a refuge, however, fishes appear to be more restricted in their movements than those using reefs. Our data show that larger parrotfishes graze primarily within a distance of $<2 \mathrm{~m}$ from the blowout, whereas reef-associated parrotfishes venture as much as $90 \mathrm{~m}$ from the reef during their feeding bouts (Macintyre et al. 1987). This difference is likely to be at least partially explained by the lack of seagrass in the unvegetated halo (typically $10 \mathrm{~m}$ wide) often found near patch reefs (Randall 1965, Ogden 1976, Ogden \& Zieman 1977). Such a halo does not exist in blowouts, as the seagrass can be found immediately at the eroding edge of the blowout.

Although seagrass blade-width was not affected by distance from the blowout, blade-length was significantly shorter at the edge of the blowout than further into the seagrass bed. Similarly, blade density increased with increasing distance from the blowout. Larger parrotfishes, however, grazed preferentially at the blowout edge, where seagrass blades where shorter and less dense. These fishes could easily swim the few meters to the area where seagrass length and density increase, but do not do so, suggesting that even the longer, more dense seagrass is insufficient to provide protection from predators.

Alternatively, our observed grazing pattern could result from ontogenetic changes in feeding behavior. Parrotfishes graze preferentially on epiphytized portions of seagrass blades (Lobel \& Ogden 1981), nitrogen-enriched blades (McGlathery 1995) and seagrass species with lower levels of refractory compounds 
(Mariani \& Alcoverro 1999). Such feeding preferences might vary with age. Some Scarus spp. parrotfishes undergo ontogenetic shifts from carnivory to herbivory as juveniles (Bellwood 1988). Qualitative observations in our study area indicate little, if any, difference in the epiphyte load of blades at varying distances from the blowout. Older fishes may selectively graze the seagrass blades near the blowout because of some particular chemical composition of which we are unaware. Given the rhizomatous morphology of Thalassia testudinum and the short distances $(<10 \mathrm{~m})$ over which our patterns were observed, however, this explanation seems unlikely.

Another possible explanation for the observed patterns of grazing is social interaction. Parrotfishes exhibit diverse social systems both inter- and intraspecifically (Robertson \& Warner 1978, Thresher 1984 [review], Shapiro 1991). Sparisoma radians, for example, is a territorial, haremic species, although many reproducing individuals remain outside established harems (Robertson \& Warner 1978, Farm 1993). If blowouts represent a significant resource (e.g. as a refuge), larger individuals might spend more time near a blowout, defending either the resource or the females that use the resource. Such behavior might explain the presence of more large bites close to the blowout as well as the increase in small bites farther from the blowout if the larger fishes are actively excluding the smaller fishes.

In conclusion, blowouts increase the habitat heterogeneity of seagrass beds and are potentially important refugia for larger parrotfishes. The grazing effects of herbivorous parrotfishes increase with increasing distance from the blowout, creating further complexity in the seagrass population. Furthermore, there appear to be important differences among individual blowouts, as shown by the significance of the blocked blowout factor in all our analyses. Although the effects of blowouts occur over a small scale $(<10 \mathrm{~m})$ relative to the size of the entire seagrass bed, many of the fish and invertebrate inhabitants of the seagrass bed spend their entire lives over such small scales. Thus, blowouts can contribute to overall heterogeneity in the structure and function of seagrass ecosystems.

Acknowledgements. We thank A. Grens, P. Bushnell, and the students of the 2002 Indiana University South Bend marine biology field course at HUML for their help in the field. We also thank N. Glass for performing many fish surveys and E. Irlandi and K. McLeod for reviews of an early draft. We are especially grateful to S. Liberal for her help in measuring countless parrotfish bite marks. This work would not have been possible without the support of J. Morrissey and E. Kaplan. We appreciate the very helpful comments of 3 anonymous reviewers. This is Contribution No. 9 of the Hofstra University Marine Laboratory.

\section{LITERATURE CITED}

Bellwood DR (1988) Ontogenetic changes in the diet of early and post-settlement Scarus species (Pisces: Scaridae). J Fish Biol 33:213-219

Bjorndal KA (1980) Nutrition and grazing behavior of the green turtle Chelonia mydas. Mar Biol 56:147-154

Bowden DA, Rowden AA, Attrill MJ (2001) Effect of patch size and in-patch location on the infaunal macroinvertebrate assemblages of Zostera marina seagrass beds. J Exp Mar Biol Ecol 259:133-154

Farm B (1993) Territory dynamics in the bucktooth parrotfish (Sparisoma radians). PhD dissertation, Universita of Minnesota, St. Paul, MN

Fonseca MS, Kenworthy WJ, Courtney FX (1996) Development of planted seagrass beds in Tampa Bay, Florida, USA. I. Plant components. Mar Ecol Prog Ser 132:127-139

Greenway M (1976) The grazing of Thalassia testudinum in Kingston Harbour, Jamaica. Aquat Bot 2:117-126

Hovel KA, Fonseca MS, Myer DL, Kenworthy WJ, Whitfield PE (2002) Effects of seagrass landscape structure, structural complexity and hydrodynamic regime on macrofaunal densities in North Carolina seagrass beds. Mar Ecol Prog Ser 243:11-24

Hyndes GA, Kendrick AJ, MacArthur LD, Stewart E (2003) Differences in the species- and size-composition of fish assemblages in three distinct seagrass habitats with differing plant and meadow structure. Mar Biol 142: 1195-1206

Irlandi EA (1994) Large- and small-scale effects of habitat structure on rates of predation: how percent coverage of seagrass affects rates of predation and siphon nipping on an infaunal bivalve. Oecologia 98:176-183

Irlandi EA, Peterson CH (1991) Modification of animal habitat by large plants: mechanisms by which seagrass influences clam growth. Oecologia 87:307-318

Irlandi EA, WG Ambrose J, Orlando BA (1995) Landscape ecology and the marine environment: how seagrass landscapes influence growth and survival of juvenile bay scallops. Oikos 72:307-313

Jolicoeur P, Mosimann JE (1968) Intervalles de confiance pour la pente de l'axe majeur d'une distribution normale bidimensionelle. Biom-Praxim 9:121-140

Kirsch KD, Valentine JF, Heck KL (2002) Parrotfish grazing on turtlegrass Thalassia testudinum: evidence for the importance of seagrass consumption in food web dynamics of the Florida Keys National Marine Sanctuary. Mar Ecol Prog Ser 227:71-85

Lobel PS, Ogden JC (1981) Foraging by the herbivorous parrotfish Sparisoma radians. Mar Biol 64:173-183

Macintyre IG, Grauss RR, Reinthal PN, Littler MM, Littler DS (1987) The Barrier Reef sediment apron: Tobacco Reef, Belize. Coral Reefs 6:1-12

Mariani S, Alcoverro T (1999) A multiple-choice feedingpreference experiment utilising seagrasses with a natural population of herbivorous fishes. Mar Ecol Prog Ser 189: 295-299

McAfee ST, Morgan SG (1996) Resource use by five sympatric parrotfishes in the San Blas Archipelago, Panama. Mar Biol 125:427-437

McGlathery KJ (1995) Nutrient and grazing influences on a subtropical seagrass community. Mar Ecol Prog Ser 122: $239-252$

Montague JR, Carballo JL, Valdes LM, Chacken M (1995) Analyses of decay and parrot fish grazing along attached blades of turtle grass (Thalassia testudinum) from two sites in Biscayne Bay. Fla Sci 58:206-215 
Murphey PL, Fonseca MS (1995) Role of high and low energy seagrass beds as nursery areas for Penaeus duorarum in North Carolina. Mar Ecol Prog Ser 121:91-98

Ogden JC (1976) Some aspects of herbivore-plant relationships on Caribbean reefs and seagrass beds. Aquat Bot 2: 103-116

Ogden JC, Zieman JC (1977) Ecological aspects of coral reef-seagrass bed contacts in the Caribbean. Proc 3rd Int Coral Reef Symp 1:377-382

O'Neal M, Landis D, Isaacs R (2002) An inexpensive, accurate method for measuring leaf area and defoliation through digital image analysis. J Econ Entomol 95:1190-1194

Patriquin DG (1975) 'Migration' of blowouts in seagrass beds at Barbados and Carriacou, West Indies, and its ecological and geological implications. Aquat Bot 1:163-189

Ramage DL, Schiel DR (1999) Patch dynamics and response to disturbance of the seagrass Zostera novazelandica on intertidal platforms in southern New Zealand. Mar Ecol Prog Ser 189:275-288

Randall JE (1965) Grazing effect on sea grasses by herbivorous reef fishes in the West Indies. Ecology 46:255-260

Randall JE (1967) Food habits of reef fishes of the West Indies. Stud Trop Oceanogr 5:665-847

Robertson DR, Warner RR (1978) Sexual patterns in the labroid fishes of the Western Caribbean. II. The parrotfishes (Scaridae). Smithson Contrib Zool 255:1-26

Salita JT, Ekau W, Saint-Paul U (2003) Field evidence on the

Editorial responsibility: Howard I. Browman (Associate Editorin-Chief), Storebø, Norway influence of seagrass landscapes on fish abundance in Bolinao, northern Philippines. Mar Ecol Prog Ser 247: 183-195

Scoffin TP (1970) Trapping and binding of subtidal carbonate sediments by marine vegetation in Bimini Lagoon, sp. Bahamas. J Sediment Petrol 40:249-273

Shapiro DY (1991) Intraspecific variability in social systems of coral reef fishes. In: Sale PF (ed) The ecology of fishes on coral reefs. Academic Press, San Diego, CA, p 331-355

Sokal RR, Rohlf FJ (1995) Biometry. The principles and practice of statistics in biological research, 3rd edn. WH Freeman \& Co, New York

Thresher RE (1984) Reproduction in reef fishes. TFH Publications, Neptune City, NJ

Townsend EC, Fonseca MS (1998) Bioturbation as a potential mechanism influencing spatial heterogeneity of North Carolina seagrass beds. Mar Ecol Prog Ser 169:123-132

Tribble GW (1981) Reef-based herbivores and the distribution of two seagrasses (Syringodium filiforme and Thalassia testudinum) in the San Blas Islands (Western Caribbean). Mar Biol 65:277-281

Valentine JF, Heck KL (1991) The role of sea urchin grazing in regulating subtropical seagrass meadows: evidence from field manipulations in the northern Gulf of Mexico. J Exp Mar Biol Ecol 154:215-230

Williams SL (1988) Disturbance and recovery of a deep water Caribbean seagrass bed. Mar Ecol Prog Ser 42:63-71

Submitted: August 1, 2004; Accepted: May 18, 2005

Proofs received from author(s): November 7, 2005 